\title{
Cooperative Model Learning Management in Assessment Training of Teaching Science and Training Malahayati Aceh Indonesia
}

\author{
Andi Hermawan Brutu \\ BP2IP Malahayati Aceh \\ Aceh Besar, Indonesia \\ yusrizal_fipunsyiah@yahoo.com
}

\author{
Yusrizal \\ Department of Educational Administration \\ Syiah Kuala University, Indonesia \\ yusrizal_fipunsyiah@yahoo.com
}

\author{
Bahrun \\ Department of Educational Administration \\ Syiah Kuala University, Indonesia \\ yusrizal_fipunsyiah@yahoo.com
}

\begin{abstract}
The purpose of this study was to determine the setting of BP2IP Malahayati Aceh which is good in empowering educators, education personnel and the entire academic community so that the education and training activities in shipping at BP2IP Malahayati Aceh can run smoothly. This research method uses a qualitative approach. Data collection techniques are interviews, observation, and documentation studies. Based on the research results obtained that: (1) planning cooperative learning model for training participants in the Sailing Science and Training Center in Malahayati Aceh has been prepared properly and correctly in accordance with the existing curriculum and adapted to existing teaching materials; (2) organizing cooperative model learning on training participants in the Sailing Science and Training Center Malahayati Aceh has been carried out systematically in accordance with their respective sequences of learning activities; (3) the mobilization of cooperative model learning for training participants in the Malahayati Aceh Science and Education Training and Training Center has been carried out according to the subject matter to be taught and the stages that apply; and (4) supervision of cooperative model learning for training participants in the Sailing Science and Training Center Malahayati Aceh has been running well and coordinated, so that the learning objectives are achieved as expected.
\end{abstract}

Keywords: cooperative model learning, management

\section{INTRODUCTION}

Through education students can develop abilities optimally and can realize their functions according to personal and community needs. For that, the most efficient step in improving the character and character of a student is through improving education. Education is an important matter and is a basic need and is absolutely necessary for the children of the Indonesian people.

This is consistent with the purpose of educating the nation state as stated in the Preamble Constitutions The Republic of Indonesia 1945, fourth paragraph. Reinforced in the body of article 31 verse 1 which states: every citizen is obliged to attend basic education and the government is obliged to finance it.

Education is one form of the realization of a dynamic and developmental human culture. Therefore changes or developments in education are things that really should occur in line with changes in the culture of life. Changes in the sense of improving education at all levels and need to be continuously carried out in anticipation of future interests [1].

Schools as formal education institutions are educational environments that provide students with learning activities, so that students gain educational experience. The teaching and learning process is a process that contains a series of actions of teachers and students on the basis of reciprocal relationships that take place in an educational situation to achieve certain goals [2].

Interaction or reciprocal relationship between teacher and student is the main requirement for the ongoing learning process. Interaction in teaching and learning events has a broader meaning, not just the relationship between the teacher and students, but in the form of educative interaction [3]. In this case not only the delivery of messages in the form of subject matter, but the planting of attitudes and values in students who are learning.

The school learning process is the process of teacher and student interaction to learn a material arranged in the curriculum. In order for the learning process to be good a teacher must be able to plan, compile and design a learning process so that learning objectives can be achieved and learning is said to be successful. researchers found that the average value of graduation National Assessment program on the subject in 2014 was 5.25. This is what reinforces that the value of students in BP2IP Malahayati Aceh is still low compared to the score minimum (KKM) in the school which amounted to 6.80 .

From the results of interviews with many students stating that conventional lessons, especially material about physics, are student lessons that are difficult to understand and boring. They also tend to think that Physics lessons are always synonymous with formulas that are many and difficult to remember. Teachers often use teaching patterns by presenting material and solving problems with formulas. Students can only count but do not understand the actual concept of physics. Finally, the KKM value (minimum completeness) was not reached only $60 \%$ of the total number of students. 
The low student learning outcomes indicate that the learning done so far has not been effective. Responding to the above problems, the need for teachers 'efforts in learning is a very important part in improving students' understanding of the physics concepts presented by the teacher, so that the learning objectives that have been planned can be achieved. Thus student learning outcomes also increase [4]. Therefore teachers as educators are expected to master a learning model that is able to help improve students' ability to understand and remember data, facts or concepts related to learning.

By looking at the conditions above it is time to be taken seriously by educators. If conditions like this continue to be left, then the quality of graduates will be lower. Therefore conventional learning that emphasizes teacher-centered needs to be reduced and replaced by an empirical learning model that emphasizes studentcentered research that has been studied, applied and proven by educators and can improve student learning outcomes and thinking skills.

Thus, an organized learning model is needed in conducting a research [5]. This is where the role of a teacher is very important, namely in motivating and facilitating students by using the most appropriate learning model. One learning model that is suitable for use in learning is the cooperative learning model.

\section{METHODS}

In this study using a qualitative descriptive approach. In general, descriptive forms of inquiry are telling and interpreting existing data, about the situation experienced, the attitude view that appears or about an ongoing process.

As for the characteristics of descriptive research, namely: (1) focusing on solving problems that exist in the present, on actual problems; and (2) the data collected is initially compiled, explained and then analyzed. Descriptive research does not intend to test hypotheses. Qualitative research is not just data collection techniques, but is a way of approaching data.

\section{RESULTS}

Learning Planning of Cooperative Model

Planning cooperative model learning on training participants in the Sailing Science and Training Center Malahayati Aceh currently arranges lesson plan (RPP) using a curriculum that is adapted to national standards and quality standards set by the relevant department. Planning cooperative learning model for training participants in the Shipping Science and Training Center of Malahayati Aceh currently has Readiness to document completeness device learning adequate and complete.

Delivery material learning that will be delivered on Participants Education and Training Hall Education and Training Science Cruise Malahayati Aceh has been adjusted to the RPP that has been prepared and in accordance with the cadets' curriculum. Schedule teach Cooperative learning model for training participants Malahayati Aceh Shipping Science and Training Center was prepared by the Curriculum Field Waka which has been adapted to the existing curriculum.

\section{Organizing Cooperative Model Learning}

Organizing cooperative model learning for training participants in the Sailing Science and Training Center Malahayati Aceh aims to limit and adjust the targets and targets to be achieved so that they can be implemented in accordance with what is expected and desired by all parties involved.

\section{Learning Movement of Cooperative Model}

The movement of cooperative model learning in training participants in the Sailing Science and Training Center in Malahayati Aceh has made adjustments to the implementation of activities with pre-determined targets so that they continue to experience movement towards a better direction.

\section{Supervision of Cooperative Model Learning}

Supervision of cooperative model learning for training participants in the Sailing Science and Training Center of Malahayati Aceh has been carried out in accordance with the function of each field that monitors it. The supervision process of cooperative model learning learning for training participants in the Sailing Science and Training Center in Malahayati Aceh is a very decisive step to be the reference material for the performance that has been done.

Supervision of cooperative model learning for training participants of the Malahayati Aceh Education and Sailing Training Center, namely by carrying out observations on the teaching carried out, an analysis of the results of the supervision was carried out. The main objective is to be followed up as seen by supervisors, as observers, towards the cooperative model learning process for training participants in the Malahayati Aceh Science and Education Training and Training Center.

\section{DISCUSSION}

As a teacher or educator, the teacher is one of the determinants of the success of every educational effort. That is why every educational innovation, especially in the curriculum and the successful improvement of human resources from educational efforts always leads to teacher factors. This shows that the role of the teacher in the world of education exists. Likewise in an effort to teach teacher students are required to have multiple roles so as to be able to create effective teaching and learning conditions. To be able to teach effectively, teachers must increase learning opportunities for students (quantity) and improve the quality (quality) of teaching them [6].

Student learning opportunities can be improved by involving students actively in learning [7]. This means more and optimal learning opportunities and the teacher shows seriousness when teaching. The more students who are actively involved in learning, the higher the probability of learning achievement. Whereas in improving the quality of teaching teachers should be able to plan teaching programs and at the same time be able to do in the form of teaching and learning interactions [8]. For the 
teacher, the success will lead to satisfaction, selfconfidence and a high spirit of teaching. This means that it has shown some of the attitudes of professional teachers needed in the era of globalization with its various advances, especially the advancement of science and technology that affect education.

Research also shows that cooperative learning has a very positive impact on students who are low in learning outcomes. Pete Tschumi from the University of Arkansas Little Rock introduced a three-time introductory computer science, the first to work individually, and twice as a group. In the first class only $36 \%$ of students got $\mathrm{C}$ grades or better, and in the class that worked cooperatively there were $58 \%$ and $65 \%$ of students who got $\mathrm{C}$ grades or better [8].

BP2IP Malahayati Aceh was inaugurated on November 23, 2011 by the Minister of Transportation and began conducting shipping and education training activities in 2013 by opening a Level IV (DP-IV) Sailor Training program and Basic Safety Training (BST) Sailor Skills Training Program (DKP), Advance Fire Fighting (AFF), Medical First Aid (MFA), and Medical Care (MC). In its development, BP2IP Malahayati Aceh experienced a very rapid development where in 2017, BP2IP Malahayati Aceh had three formation seafarers training programs, namely the Training of Jaga Office of Defense, DP-III and DP-IV Formation, four improvement programs for seafarers training namely DP-III Improvement, DP-IV Improvement, DP-V Improvement, and Able Seafares. Good management in the world of education in Indonesia is expected by all Indonesians.

The management carried out in managing each component will have an impact on the success or failure of education and learning [8]. In the process of dynamic quality interaction between heads, teachers, administrative staff, and students play a very important role, especially in adjusting various school activities with the demands of globalization, changes in society, the development of science and technology, as well as the demands of the situation, conditions and environment [1]. All of them are very demanding of competence and professionalism to enable the creation of dynamic quality interactions.

This is very much different from students in the past few years who showed antusism that was high when given problems. The results of the preliminary study in the form of observations at BP2IP Malahayati Aceh found that the teaching and learning process that still uses conventional systems with direct learning where the teacher dominates learning despite the varied questions and answers with students. Teachers convey more material directly to students [4]. This shows that science learning is still carried out by transfer of knowledge so that learning tends to be verbal and oriented towards students' cognitive abilities without considering the process of acquiring that knowledge. The phenomenon of teaching that does not involve students directly in teaching and learning causes students to lack psychomotor and affective abilities.

Students rarely discuss and cooperate with other students which results in students being passive. Most students are only oriented to cognitive abilities and assume that learning is a memorized subject [4]. Even so, actually learning using conventional systems is good, but there are still many shortcomings here and there that result in ineffective learning processes, because the learning process is too concentrated in the teacher who gives almost $100 \%$ material explanation and results in students being passive.

\section{CONCLUSION}

Planning cooperative model learning on training participants in the Sailing Science and Training Center in Malahayati Aceh has been prepared properly and correctly in accordance with the existing curriculum and adapted to the existing teaching materials. Organizing cooperative model learning for training participants in the Sailing Science and Training Center of Malahayati Aceh has been carried out systematically in accordance with their respective sequences of learning activities carried out.

The implementation of cooperative model learning for training participants in the Malahayati Aceh Science and Education Training and Training Center has been carried out according to the subject matter to be taught and the stages that apply. Supervision of cooperative model learning on training participants in the Sailing Science and Training Center in Malahayati Aceh has been running well and coordinated, so that the learning objectives are achieved as expected.

\section{REFERENCES}

[1] Andri, P. 2014. The Effect of Group Investigation Learning Model, Accelerated Learning Team and Role Playing on Elementary School Students' Writing Skills Viewed from Cognitive Style. Thesis. Surakarta: State University of Surakarta.

[2] Arends. 2017. Learning to Teach Learning for Teaching. Yogyakarta: Pustaka Pelajar.

[3] Dahar, RW 2014. Learning and Learning Theories. Jakarta: Erlangga.

[4] Daryanto. 2015. Learning Media. Bandung: Satu Nusa.

[5] Dimyati, \& Mudjiono. 2013. Learning and Learning. Jakarta: Rineka Cipta.

[6] Ferries, N., Harun, C. Z., \& Usman, N. 2017. Banda Aceh: Teacher Learning Management at Peukan Pidie 1 Public Elementary School in Pidie District. Journal of Postgraduate Education Administration, 5(4), 224-228.

[7] Melda. 2012. Understanding Concept Analysis and Physics Problem Solving Ability Using Group Investigation Cooperative Learning Models and Direct Learning Models. Journal Online Physics Education.

[8] Nilufer, \& Kemal. 2012. The Effect of Group Investigation and Cooperative Learning Techniques Applied in Teaching Force and Motion Subjects on Students' Academic Achievements. Journal Education Research Research. 